\title{
sobider
}

Sosyal Bilimler Dergisi / The Journal of Social Sciences

Akademik Sosyal Araştırmalar Dergisi, Yıl: 7, Sayı: 45, Nisan 2020, s. 482-491

ISSN: 2149-0821 Doi Number:http://dx.doi.org/10.29228/SOBIDER.41892

Ziwar RASOOL

Selçuk Üniversitesi, Sosyal Bilimler Enstitüsü, Sosyoloji Ana Bilim Dalı, Yüksek Lisans

Öğrencisi, ziwar.zrar@gmail.com

\section{TOPLUMSAL TABAKALAŞMANIN BİR ARACI OLARAK KÜLTÜREL SERMAYE}

Özet

Çalışmanın amacı, kültürel sermaye ve toplumsal sınıf arasındaki ilişkiyi ve bunun toplumsal tabakalaşmanın oluşumu üzerindeki etkisini incelemektir. "Kültürel sermaye" bir grubun paylaştı̆̆ kültürel eğilim, davranış, inanç, gelenek, değer, iş yapma tarzı ve ifade neticesinde öğrendiği veya edindiği beceriler olarak tanımlanmaktadır. Kültürel sermaye bir bütün olarak bireyin beğenilme tarzını araçlarla sosyal seçimi seferber edecek şekilde ortaya çıkarmaktadır. Böylelikle, beğeniler/zevkler kültürel sermayenin taşıyıcısı olarak sosyal farklılıkların belirticisidir. Pierre Bourdieu'ye göre, kültürel sermaye eğitim ve aile araçlarıyla toplumsal tabakalaşmanın üretildiği ya da yeniden üretildiği bir sermaye türüdür. Öte yandan, sınıfın içinde ya da sınıfların arasında ekonomik sermaye durumu kültürel sermayeye de etki etmektedir. Orta ve üst sınıflar ekonomik sermayeyi kültürel sermayeye aktarmaya çalışmaktadır. Toplumda bireylere sunulan varlıklar dağılımı sosyal hiyerarşi ve bireyler, güç, imtiyaz veya etki etmek için bu mücadele belirli sınıf konumlarını belirleyen ve meşrulaştırıcı bir şekilde ilerleyen kültürel eşitsizlik dağılımına dayanmaktadır. Dolayısıyla, bu durum bireyler arasında bir farklılaşma sistemi oluş̧urmaktadır.

Anathar kelimeler; Kültürel Sermaye, Toplumsal Tabakalaşma, Eşitsizlik, Yetenekler, Beğeniler 


\title{
CULTURAL CAPITAL AZ A TOOL OF SOCIAL STRATIFICATION
}

\begin{abstract}
The main purpose of this study is to examine the relationship between cultural capital and social class structure and it's the effect on the formation of social stratification. Cultural capital is defined as the cultural tendency, lifestyle, behavior, belief, tradition, value, the way of doing business and the skills learned or aquired as a result of a group's sharing. In this aspect, cultural capital reveals the individual's taste as a means of mobilizing social choice. According to Pierre Bourdiue, cutlural capital is a type of capital in which social stratification is produced or reproduced through education and family tools. On the other hand, the economic capital stitutions also has affected cultural capital. Therefore, the middle and upper classes are tries to transfer the economic capital to cultural capital. The distribution of assets offered to individuals in society is based on the social hierarchy and the distrabution of cultural inequality that determines and classifies certain class positions for individuals. Therefore, this situation is great a differentiation system among individuals.
\end{abstract}

Keywords, Cultural Capital, Social Stratification, Inequality, Skills, Tastes.

\section{GíRİș}

Kültürel sermaye sosyalleşme süreci içerisinde okul ve aile kurumlarını ele almaktadır. Aynı zamanda kültürel sermaye kültürün tabakalaşma olgusu üzerindeki etkisi ve sosyal yapının ve eylemin arasındaki ilişkiyi incelemek için kullanılmaktadır. Kültürel sermaye, kültürel tutum, tercihler ve davranışlar araçlarıyla sınıf pozisyonunu belirlemektedir. Öte yandan kültürel sermaye bir bütün olarak bireyin beğenilme tarzıyla sosyal tercihlerini göstermektedir. Bu çerçeve içerisinde kültürel sermaye sosyal farkl11ıklar ve sosyal ayrımları temsil etmektedir. Öte yandan, kültürel sermaye hem sosyal eşitsizliğin bir nedeni olarak hem de ekonomik sermayeye etki ettiğinden toplumda ve bireyler arasında sosyal tabakalaşmayı doğurmaktadır.

Pirrer Bourdieu eğitimi sistemini kültürel sermayenin belirleyicisi olarak görmektedir. Ona göre eğitim kurumları sosyal eşitsizlikleri değiştirmekten daha çok toplumdaki mevcut eşitsizlikleri kuram ve toplumsal yapının yeniden üretimiyle devam ettirmektedir. $\mathrm{Bu}$ anlamında, sosyal farklılıkları anlamak için önce eğitim sistemi, aile, yaşam tarzı, kültür ve habitusu inceleyip bunların kendi arasındaki ilişkiyi, aynı zamanda toplum yapısı arasındaki ilişkiyi incelemek gerekmektedir. Çünkü bireyin aile yapısı, bireysel yetenekler, beceriler ve kültürel eğilimler bireyin kültürel sermayesinin durumunu belirtmektedir.

Yüksek mesleklere sahip olan aileler kendi sosyal, ekonomik, kültürel kaynaklarını çocuklarına aktararak çocuklarının da başarılı olmalarını sağlamaktadırlar. Böylece, kendi toplumsal konumu ve ekonomik sermayelerini sürekli sürdürmektedir. Çünkü meslek, aylık gelir, yaşam yeri, eğitim düzeyi bireyin toplumsal pozisyonuna etki etmektedir. Bu çalışma kültürel sermaye ve toplumsal sınıflaşma arasındaki ilişkiyi tartışmaktadır. 


\section{Sosyal Sınıflar ile İlgili Kuramlar:}

\section{Karl Marx;}

Karl Marx (1818-1883) klasik sosyal bilimcilerden ve aynı zamanda sosyolojinin kurucularından biridir. Sosyal sınıflarla ilgili Marx'ın yaklaşımları ondan sonra gelen sosyologlar ve ekonomi bilimciler için oldukça önemlidir. Marx, dönemindeki sosyo-ekonomik koşulları gözlemleyerek sosyal sınıflar için toplumsal açılamalar öne sürmüştür.

Marx 19. Yüzyılda İngiltere'deki sosyal ve ekonomik durumu bilimsel ve detaylı bir şekilde inceledikten sonra sosyal sınıflarla ilgili kendi düşüncelerini ortaya koymuştur. İngiltere'deki ekonomik gelişmeler Marx'ın toplumsal sınıfların birbirinden ayrıldığı tezini kanıtlamaya yardımc1 olmuştur (Başaran 2017: 228).

Marx’a göre, sınıf üretime bağlı olan bir sistemdir. Bir diğer deyişle, sınıf bir grup insanların üretim araçları ile ortak ilişki içinde bulunması durumudur. Böylece, bu grup insanlar arasında bazı ortak ekonomik menfaatlerden dolayı ortak bir yaşam tarzı ortaya çıkmakta, sosyal yapı içerisinde üretim sürecine göre siyasal ve ideolojik roller belirlenmektedir. Başka bir ifadeyle, Marx için sınıf, birtakım insanların üretim araçlarını kullanarak sosyal ve ekonomik hedefler gerçekleştirmek için bir araya toplanmasıdır. Ayrıca Marx'ın sınıf teorisine göre, toplumda temel olarak iki sınıf vardır: birincisi, üretim araçlarına sahip olanlar, ikincisi ise üretim araçlarına sahip olmayan sınıflardır (Shwani 2011: 50).

Karl Marx ilk sosyolog olarak, sosyal sınıfları toplumsal dünyayı diyalektik ve materyalist yönteme dayanarak toplumsal farklılıkları incelemektedir. Marx'ın tabakalaşma teorisinde sınıf, devlet ve üretim tarzı toplumsal farklılıkları belirtmek için öne çıkarılmaktadır. Marx, tarihi ve toplumsal yapıları incelerken sınıf ve sinıflar arasındaki mücadeleleri önemsemektedir. Yani, Marx için üretim araçları ve sınıf mücadelesi merkezi bir rol oynamaktadır (Kızılçelik 2013: 169-170).

Marx'a göre, kapitalist toplumunda sadece iki kural geçerlidir. İlki büyük hacimli sermaye ve/veya para birikimi olmakla paranın belli bir grup insanların elinde kalmasıdır. İkincisi ise yoksullaştırma olgusudur. Modern toplumlarda endüstrileşme ve makineleşme sürecinden dolayı büyük fabrikalar ve bu fabrikalardaki alt sınıflar işçi olarak çalışmaktadır (Şengönül 2008: 178). Dolaysıyla Marx'a göre, kapitalizm işçileri fakirleştirip toplumda onlara az iktidar ve güç sağlar. $\mathrm{Bu}$ durumdan dolayı, alt sınıfların arasında yabancılaşma olgusu ortaya çıkmaktadır.

Marx'a göre, temel olarak toplumsal farklılıklar ancak üretim araçları yoluyla belirmektedir. Ona göre, toplumların tarihinde sürekli ezen ve ezilen iki zit grup insanlar olmuştur. Dolayısıyla, bu zıtlık sonunda sınıf çatışmasının nedeni olmuştur. Bir diğer deyişle, üretim araçlarına sahip olan ve üretim araçlarına sahip olmayan grupların arasında bir sosyo-ekonomik ayrım ortaya çıkmaktadır. Ona göre, ilk olarak özel mülkiyetin ortaya çıkmasından dolayı toplumun bütün üretim araçları hakim sınıfın elinde kalmıştır (Avc1 2019: 560). Marx, özel mülkiyetin üretim açısından sınıf çatışması temelli bir nedeni olduğunu, üretim sürecinde çalışanlar için emeğin hayatla eşdeğer bir anlam ifade ettiğini belirtmiştir. Başka bir anlatımla, özel mülkiyet üretim anlamında sınıfların sömürülmesine olumsuz bir şekilde etki etmiştir. Çünkü iş sahibi işçilere yalnızca ürettiği kadar ücret vermekteydi (Lohmson 2013 :157). 
$\mathrm{Bu}$ şekilde, üretim araçlarına sahip olmayanlar hayatını sürdürebilmek için egemen sınıflara her zaman muhtaç kalmaktadır. Dolayısıyla, Marx’a göre tarihsel bir süreç içerisinde toplumların ekonomik sistemi adaletsiz olduğundan sınıf sömürüsü vardır. Sınıf sömürü olgusuyla alakalı bir şeydir. Bu yüzden toplumda sınıflar ortaya çıktığında sınıf sömürüsünü de beraberinde getirmektedir (Kızılçelik 2013: 172).

\section{Max Weber;}

Sosyal sınıflarla ilgili Weber'in yaklaşımları sosyal bilimciler arasında oldukça önemli bir yere sahiptir. Weber'in kuramları hem geniş hem de kapsamlıdır. Marx gibi Weber de yaşadığ 1 dönemden günümüze kadar sosyoloji literatürü için çok önemlidir.

Weber, Marx'ın yaşadığı dönemlere yakın bir dönemde yaşamıştır ve kapitalizmin sosyoekonomik bir sistem olarak gelişmesine şahit olmuştur. Dolayısıyla Weber, Marx'ın sosyal eşitsizlik, sosyal sınıflar analizi ve tabakalaşma teorisini olumlu bir şekilde eleştirmiştir. Başka bir ifadeyle, Weber Marx'ın yaklaşımlarını eleştirerek kendi düşüncelerini geliştirmiştir. Böylelikle, Weber çoğu zaman farklı sonuçlara ulaşmıştır. Marx ve Weber'in en dikkat çeken noktası sosyal tabakalaşma ve sosyal sınıflardan ziyade kapitalizmin gelişmesidir (Aydın 2018: 248). O dönemde yeni ortaya çıkan kapitalizm, sanayileşme ve kentleşme ve bu olguların toplumsal hayatı dönüştürmesi her iki sosyoloğun ilgisini çekmiştir.

Weber'e göre, sosyal sinıflar olgusu sosyolojide temel konulardan biridir. Sosyal sinıflar incelendiğinde hem ekonomik hem de siyasal boyutlar açısından değerlendirilmektedir. Weber'e göre, bir kişiyi belirli bir sosyal sınıf açısından değerlendirebilmek için genel olarak üç unsur vardır:

- İlk unsur ekonomik durum ve sosyal sınıfla piyasa arasındaki ilişkidir. Yani, kişinin piyasada oynadığı rol dikkate alınmaktadır.

- İkincisi bireyin sosyal sınıfını belirleyen sosyal statüdür. Sosyal statü sadece mülkiyet, ya da sermaye ile elde edilmez, birey başka şekilde de kazancını temin edebilmektedir. Dolayısıyla, sosyal statü siyasi ve ekonomik durumlara olumlu bir şekilde etki etmektedir.

- Üçüncü unsur ise siyasal parti, güç ve iktidarla ilgilidir. Bu da ilk başta bireysel beceriler ve yetenekler yoluyla elde edilmektedir (Shwani 2011: 40-41).

Weber'in toplumsal tabakalaşma kuramı içerisinde sosyal sınıfların yanında sosyal statü, politik partiler ve meslek örgütleri de vardır. Sınıf durumu ekonomik koşullar ve gelir düzeylerine göre belirlenmektedir. Sosyal statü ise belirli bir yaşam tarzının kalıplaşmış ve sosyal onuru yansıtmaktadır. Politik partilerde siyasal iktidar gibi kuruluşlar vasıtasıyla toplumsal eşitsizlikler üretilmektedir (Eyce 1975: 284). Weber'in sosyal sınıf teorisi hem eski toplumların toplumsal farklılıklara hem de modern toplumlardaki toplumsal tipleri üzerinde uygulanabilmektedir. Weber'e göre, Marx'ın sınıf kuramı açıklaması modern toplumlardaki sınıfsal hareketliliği incelemek için tatmin edici değildir. Weber, toplumsal tabakalaşmayı Marx'tan daha geniş bir şekilde incelemektedir (Alpman 2009: 28).

Weber'e göre, sınıf posizyonu önce gelir düzeyi ve bireyin mülkiyet durumu, sonra da piyasadaki isteklere göre değişmektedir (Weber 2006: 271). Ona göre, siniflar toplumsal cemaatler değildir. Fakat sosyal sinıflar toplumsal hareketlerin temellerini temsil etmektedir. Ona göre, bir sınıfın ortaya çıkışı için temel olarak bazı şartlar lazım. Birinci, bir grup insanın yaşam olanaklarının belli bir nedensel öğesi ortak ise, ikinci bu öğeyi gelir düzeyi ve ekonomik 
durumu temsil ediyorsa, üçüncü ve son ise bu öğe meta ve işgücü piyasalarının durumlarında temsil ediyorsa, sinıf söz edilebilmektedir (Weber 2006: 277).

\section{Pierre Bourdieu;}

Bourdieu'nün sınıf yaklaşımlarına bakıldığında Marx ve Weber gibi pek çok teorisyenlerin etkisi görünmektedir. Fakat Bourdieu'nün teorisi en çok Weber'in tabakalaşma sistemine benzemektedir. Özellikle Weber'in sınıf ve statü ile ilgili düşüncelerinden etkilenmiştir. Bourdieu, Weber'in sinıf ve statü grupları arasındaki farklılıkları ekonomik ve sembolik etkenler arasındaki bir ayrım olarak görmektedir (Yanıklar 2010: 123). Bourdieu için toplumsal sınıf bir grup insanların bir araya gelip benzer yaşam tarzını yaratma durumudur. Bu grup içinde benzer yatkınlıklar, günlük pratikler ve benzer toplumsal konumların oluşması gerekmektedir. Ayrica yeni sinıflar ortak habitusa sahip biyolojik bireylerdir (Swartz 2013: 215).

Bourdieu “Ayrım, Beğeni Yargısının Toplumsal Eleştirisi” adlı kitabında sosyal sınıflar, beğeni, ve yaşam tarzları arasındaki ilişkiyi incelemeye çalışmaktadır. Bu kitabın temel konusu, bir taraftan sosyal sınıflar arasındaki farklılıklar ve bireyin yaşam tarzına etkisi, diğer taraftan ise ortak sınıfsal konumu paylaşan insanlar ortak beğenilme türü yaratmasıdır (Sunar 2018: 111).

Bourdieu toplumda temel olarak sınıfsal farklılıkları üç kategoriye ayırmaktadır. Onlar işçi sınıf, küçük burjuvazi ve orta sınıf ve üst sınıflardır. Bu gruplar kendi içerisinde ekonomik ve kültürel sermayelerine göre alt bölümlere ayrılır. Örneğin, üst sınıf ve burjuvazi yüksek bir ekonomik sermayeye sahip olabilmektedir. Fakat ona göre bireyin sosyal pozisyonu en çok ekonomik sermaye, daha sonra kültürel sermayeye göre belirlenmektedir (Bourdieu 2017: 16). Her sosyal sınıfın (üst, orta ve alt) ayrı ya da özel bir yaşam biçimine sahip olması sınıflar arasında bir farklılık ortaya çıkarmaktadır. Sonunda bu farklılık sınıf üyelerinin davranışlarını, vücut ve yüz süslerini, konuşma tarzlarını, giyim biçimlerini, okuma ihtiyaçlarını vb. oluşturmaktadır (Dönmezer 1984: 322). Öte yandan, Bourdieu, bireyin eğitim durumu, toplumsal sinıf ve toplumsal statüsüne göre üç tür beğenilme düzeyini ayırmaktadır. Birincisi, "meşru beğeni"dir. $\mathrm{Bu}$ tür beğeni kültürel sermayesi yüksek olan ve egemen sınıfa dahil olabilmektedir. İkinci tür beğeni "orta sınıf beğenisi”dir. Bu da orta sınıf ve üst sınıf entellektüelleridir. Son tür beğeni ise "popüler beğeni”dir. Bunlar da eğitim düzeyi düşük olan işçi sınıflarının beğenisidir (Bourdieu 1984: 16). Bourdieu, sosyal gruplarla toplumsal statü arasındaki ilişkiyi anlayabilmek için ilk önce kültürel beğeni ve hayat tarzını incelemektedir (Swartz 2013: 22).

Bourdieu toplumsal sinıfları incelerken tüketim kültürü ile hayat tarzı arasındaki benzerlikler üzerinde çalışmaktadır. Dahası Bourdieu, sosyal sınıflar alanı ve yaşam tarzı alanı arasında yapısal bir benzeşimin var olduğunu iddia etmektedir. Böylelikle, Bourdieu sınıf ile hayat tarzı arasındaki ilişkiyi bir taraftan mütekabiliyet diğer taraftan karşılıklı metotlar içinde kullanmaktadır. Bireyin gündelik hayat pratikleri sınıf beğenilme türüne göre ayrılmaktadır. Dolayısıyla, kendi yeme, içme, dekorasyon, siyasal faaliyetler, dil vb. oluşturmaktadır (Bourdieu 1984: 208).

Bourdieu, üç temel sermaye türünü ayırt etmektedir. Birincisi ekonomik sermaye (maddi ve parasal değerler), ikincisi kültürel sermaye (sosyal statü, beceriler ve unvanlar), üçüncüsü ise sosyal sermaye (sosyal ilişkiler, ya da bir grup içinde bireyin kazanımlar) oluşturmaktadır. Son tür sermaye türü olan simgesel sermaye herhangi algı kategorileriyle kavrandığında büründüğü biçimdir (Özel 2019: 35). Ayrıca bu tür sermayeler kendi içerisinde birbirine dönüşebilmektedir. 


\section{Kültürel Sermaye:}

Sermaye terimi çoğu zaman ekonomik anlama sahip olmakla daha çok ekonomik sermaye kastedilmektedir. Fakat son dönemlerde sermaye kavramı diğer tür sermayeler için de kullanılmaktadır. Bu tür sermayelerinden biri "kültürel sermaye"dir. Basit bir anlatımla kültürel sermaye, akademik başarıyı doğal beceri, bireysel yetenekler veya zekânın bir etkisi olarak kabul edilen yaklaşımların temel varsayımlarından uzaklaşma anlamına gelmektedir (Yanıklar 2010: 124). Kültürel sermaye çeşitli kültürel ürün, hizmet, aktiviteler, dernek gibi boyutları kapsamaktadır. Örneğin, kültür yatırımcılığı tasarım, miras, turizm, genel kültür harcamaları, müzeler, sanat ve müzik sektörü kültürel sermayenin içerisine girmektedir. Öte yandan son yıllarda yaratıcı endüstriler de kültürel sermayenin bir parçası olarak sayılmaktadır (Ekşioğlu 2012: 15).

Modern sosyolojide kültürel sermaye kavramı ile ilgili pek çok araştırmalar yapılmıştır. Literatürde kültürel sermaye kavramı farklı şekillerde tanımlanmaktadır. Genellikle sosyolojide "kültürel sermaye" bir grubun paylaştığı kültürel eğilim, davranış, inanç, gelenek, değer, iş yapma tarzı ve ifade neticesinde öğrendiği veya edindiği beceriler olarak tanımlanmaktadır (Ekşioğlu 2012: 14-15). Kültürel sermaye, bireyin çocukluk döneminden başlayarak edindiği dil ve sanat, bilim vb. ürünlerden faydalanarak biriktirilen bilgi ve becerilerden oluşan donanımdır (Karataş 2013: 138) Bourdieu'ye göre, kültürel sermaye herhangi bir eğitim ve öğretim faaliyetleri kimilerine göre insan sermayesi, kimilerine göre ise kültürel sermaye olarak adlandırılmaktadır (Kapu 2008: 264).

Bourdieu'ye göre kültürel sermaye üç formda bulunmaktadır. Birincisi, cisimleşmiş form olarak bedenin ve zihnin devamlı bir şekilde eğilimlerini ifade etmektedir. İkincisi, objeleşmiş form olarak kültürel eşya halinde örneğin, kitap, resim, sözlük, makine vb.dir. Son olarak ise kurumsallaşmış form olmakla, bireyin eğitim sürecinde aldığı ya da öğrendiği bütün bilgileri kültürel sermaye olarak görülmektedir (Şahin 1986: 3). Bourdieu'ye göre, konumun gelişmiş toplumlarda anlam kazanmasında eğitim kurumunun önemi fazladır. Dolayısıyla, ekonomik sermayenin kültürel sermayeye dönüşmesi teknik olarak mümkün olmaktadır (Erdoğan 2018: 30-31). Kültürel sermaye genellikle kültürün birikimi içine girmektedir. Ekonomik sermaye bireyin toplumun iktisadi kaynaklarıyla alakalıdır, fakat kültürel sermaye ayrı bir tür sermaye olarak bireylerin ve toplumların kültürel birikimi, dil yetenekleri, düşünme biçimi, dünya ve hayat görüşüyle ilgilidir. Bireyin eğitim düzeyi ne kadar yükselirse kültürel sermayesi de o kadar yükselir. Yapılan araştırmalara göre, eğitim düzeyi ve bireyin sanata katılımı kültürel sermayenin önemli unsurlardandır (Ekşioğlu 2012: 15). Bourdieu'ye göre, bireyin kültürel sermayesi ne kadar artarsa ve ekonomik sermaye arasındaki boşluk ne kadar çoğalırsa kişinin yerleşik düzenin işleyişine karşı tavır almaları da o derece yüksek olmaktadır. Bunu bir örnekle açıklamak gerekirse toplumdaki alt sınıfın haklarını savunan akademisyenlerin toplumdaki statüsü düşünülebilir (Erdoğan 2018: 31).

Bourdieu çalışmalarında sosyal gruplar arasındaki kültürel semboller, üstünlük ya da farklılıklar üzerinde durmuştur. Bourdieu, bunları açıklayabilmek için kültürel sermayeyi bir metafor olarak kullanmaktadır. Bourdieu insan sermayesini kültürel sermaye olarak adlandırmaktadır. Ayrıca Bourdieu değerler ve düşünme sisteminin hareket gelişimini yalın bireylerle objektif konumlar arasında araç kurma işlevine vurgu yaparak ifade etmektedir (Kapu 2008: 263). 
Bedenlenen sermaye kişinin temamen ait olan bir sermayedir. Bu tür sermaye dişsal zenginlik, para, mülkiyet, miras satın alma ya da mübadele araçlarıyla ele alınmaz. Böylece kültürel sermayenin kullanımı ya da işletimi, ister özel işverenler ta da diğer uçtaki, belirli bir külütürel yeterliğe sahip idareciler çalıştıran girişimcilere belirli problemler doğurur. Dolayısıyla, bu tür sermaye bireyin kendisiyle çok yakından alakalıdır (Şahin 1986: 4).

Son olarak, kültürel ve ekonomik sermayenin aktarılma konusunda bir süreç içerisinde ele alındığında bazı benzerlik ve farklılık görünmektedir. Bu iki tür sermayenin arasındaki temel benzerlik her ikisinde aktarma sürecinin toplumsal üretimin bir tekniği olarak aile içinde ve aracılığıyla gerçekleşmesidir. Diğer taraftan, ekonomik sermayenin aktarılması çok hızlı bir şekilde gerçekleşebilir. Fakat kültürel sermaye onun aksine çoğu zaman uzun bir süreç içerisinde gerçekleşmektedir. Bu süreç sosyolojide sosyalleşme kavramıyla ifade edilmektedir. Gerçi Bourdieu, hiç bir zaman bu kavramı kullanmamıştır. Bourdieu'ye göre, kültürel sermaye ekonomik sermayeye göre aktarımın çok zor bir süreç olduğunu vurgulamaktadır (Yakınlar 2010: 125).

\section{Kültürel Sermaye ve Sınıf Oluşumu;}

Bourdieu'ye göre temel olarak dört tür sermaye (ekonomik, kültürel, sosyal ve sembolik) vardır. Birey toplumda belirli bir sosyal sınıfta olabilmek için tüm sermaye türlerini kullanmaktadır. Bir diğer deyişle, modern toplumlarda artık birey sadece ekonomik, ya da maddi araçla üst sınıfta yer almamaktadır. Bazen birey kültürel, ya da sosyal sermayeyle egemen sınıfa dönüşebilmektedir. Fakat her zaman ekonomik ve kültürel sermaye öncelikli olmakla sınıflaşma sürecinde merkezi bir rol oynamaktadır. David Chaney sınıf beğenilerini bireylerin hayat tarzını belirleyen bir unsur olarak görmekte ve belli bir grup içinde özel bir duygu ortaklığının var olduğuna işaret etmektedir. Ona göre, bu ortak duygular günlük hayatta sürekli tekrarlanmaktadır. Bazı düşünceler veya müzik, yemek veya giyim zevkleri gibi unsurlar spesifik bir cemaatin ortak bir yakınlık algısını oluşturmakla birleştirici bir biçim kazanmaktadır (Kahraman 2009: 84).

Bourdieu, Ayrım Teorisi kitabında genel olarak işçi sınıfı, küçük burjuvazi ve orta ve üst sınıflar olmakla üçlü bir sınıf ayrımından bahsetmektedir. Bu sınıflar kendi içinde kültürel sermayeye göre alt kesimlere ayrılmaktadır. Örneğin, burjuva yüksek bir ekonomik sermayeye sahiptir. Fakat iş adamları ve entellektüeller arasındaki kültürel sermaye düzeyleri farklı olduğundan bu sınıf içinde ayrılmaktadır. Böylelikle, bireyin toplumsal konumu en çok ekonomik sermayeye, daha sonra kültürel sermayeye göre şekillenmektedir. Öte yandan, kültürel sermaye ve habitus arasında yapısal bir ilişki vardır. Habitus bireyin gündelik pratikleri, alışkanlıkları ve yatkınlık olarak ifade edilmektedir. Kültür enformasyonu olarak yeme, içme, giyim şekli, ses tonu vurgusu, konuşma tarzı, bedensel hareketlerin tümü bireyin habitusu olarak adlandırılmaktadır. Habitus hem toplumsal dünyanın anlamına ilişkin kalıcı hem de spesifik bir sosyal gruba ve sınıf fraksiyonuna özgü bir anlayış tarzıdır. Aynı zamanda bunun bir sonucu olarak ortaya çıkan farklı kültürel tarz ve eğilimlerdir (Yakınlar 2010: 125).

Bourdieu için eğitim kültürel sermayenin önemli bir boyutudur. Eğitim sadece eğitsel hedefleri ele almamakla birlikte bireyin kültürel ve sembolik eğilimleri de hedeflenmektedir. Öte yandan, aile de eğitim gibi bireyin kültürel sermayesine etki etmektedir. Dolayısıyla, hem okul hem de aile tarafından bireyin davranış ve düşünce sistemi yeniden üretilmektedir. Böylece, toplumda bireyin kültürel sermayesini çerçeveleştirmek için ilk önce aile ve eğitim kurumları 
kullanılmaktadır. Toplumsal sınıflar arasında öğretmen, okul ortamı, eğitim kalitesi bir sosyal gruptan diğerine değişmektedir. Bu nedenle egemen sınıfların üyeleri pek çok kültürel ve sosyal bilgi ve hünerlere sahiptir. Alt sınıfta bulunan çocuklar bu hünerlere sahip olabilmek için okula gitmektedir. Bu süreçte okul ya da eğitim sistemi tarafsız bir kurum değildir. Okul çoğu zaman hakim sınıfın deneyimlerinin yansitıcısıdır. Alt sinıfların üyeleri her ne kadar orta ve üst sınıflara ait kültürel, sosyal ve hünerler ediniyor olsa bile orta ve üst sinıf üyeleri gibi bu hünerleri rahat bir şekilde geliştiremezler. Böylelikle, okul ve aile sosyalizasyon süreci aracılığıyla edinilen kültürel sermaye sınıfsal konumu belirletici olarak önemli bir rol oynamaktadır (Arun 2009: 79). Başka bir anlatımla, orta sınıfın üyelerinin daha iyi eğitim almaya çabalaması aynı zamanda okulun başarılı olmasına karşın, alt sınıf çocuklarının başarılı olmaması kültürel sermayenin eksikliğinden kaynaklanmaktadır (Payabıyık 2011: 134).

Bourdieu, Marx'ın aksine kültürel sermayeni toplumsal tabakalaşmanın üretildiği ya da yeniden üretildiği bir sermaye türü olarak görmektedir. Bazı toplumlarda eğitim kalitesi düşük olması veya sınav sisteminin sürekli değişmesi nedeniyle karmaşık bir sistem oluşmaktadır. Bu nedenle ekonomik ve kültürel sermayeye sahip olan bazı ailelerin çocukları daha yüksek bir düzeyde açık öğretime gönderilmektedir. Dolayısıyla, ailelerin kültürel sermayesi eşit olmamakta ve bu eşitsizlik öğrencilerin başarılı olmalarına etki etmektedir (Karataş 2013: 138).

Bourdieu'nün kültürel sermaye ve sosyal tabakalaşma arasındaki ilişki için temel fikri şöyledir ki bireyin kültürel sermaye düzeyi kültürel yatkınlıklar, dil kullanma becerileri ve diğer tür beceriler bireyin eğitim alanlarındaki başarılarında oldukça önemlidir. Yapılan araştırmalara göre, bireyin terbiyeye ait olan başarıları daha çok doğuştan yeteneklerin ve bireyin içsel yatkınlıklarından kaynaklanmamakta, sosyalizasyon süreci içerisinde ele alınmaktadır. Diğer taraftan Bourdieu'ye göre, alt sınıfın üyeleri ya sistem tarafından dışlanmalarından dolayı ya da mevcut olan sistemden kendilerini yabancı hissettikleri için bu sınıfın eğitim düzeyi düşük kalmaktadır. Bu halde toplumsal sınıflar arasında yapısal farklılıklar oluşmaktadır (Yanıklar 2010: 127). Dolayısıyla, bu durum bireyin toplumsal konumunu kazanma hiyerarşilerine dönüşerek, yalnızca eğitsel eşitsizliğin meşru olduğunu belirtmektedir (Payabıyık 2011: 134).

Öte yandan, ekonomik sermayesi yüksek olan gruplar diğer tür sermayeleri örneğin, kültürel, sosyal ve sembolik sermayeyi geliştirmektedir. Bu yüksek sermaye bireyin bireysel tercihlerini, davranışlarını ve toplumsal konumunu etkilemektedir. Başka bir ifadeyle, benzer sermaye düzeylerine sahip olan kişiler hem benzer davranış ve düşünce sistemine hem de benzer yaşam yeri ve mevkilerinde bulunmaktadır (Karataş 2013: 138). Kısacası, kültürel tercihler, davranış ve düşünme sistemi, yani kültürel sermaye bir bütün olarak bireyin beğenilme tarzı araçlarıyla sosyal seçimi seferber edecek şekilde ortaya çıkmaktadır. Böylelikle, beğeniler/zevkler kültürel sermayenin taşıyıcısı olarak sosyal farklılıkların belirleyicisidir (Arun 2009: 79).

\section{SONUÇ:}

Bireyin kültürel sermaye durumu yaşam tarzı (habitus) eğitim düzeyine göre belirlenmektedir. Dolayısıyla, bu iki unsur bireyin hayatına en çok etki eden unsurlarındandır. Böylece kültürel sermaye kendi belirlediği fonksyonlar araçları ile birey için düşük ya da yüksek bir toplumsal konumu yaratmaktadır. Genel olarak bakıldığında bireyin hayatında önem verdiği alanlar, bireye nasıl ve hangi yollarla etki ettiğini ve bireyler arasında nasıl bir farklılık yaratığını görünmektedir. Bir diğer deyişle, toplumda bireylere sunulan varlıkların dağılımı örneğin, güç 
iktidar, imtiyaz vb. şekilli gruplar arasında farklı sosyal hiyerarşi oluşturmaktadır. Dolayısıyla hem ekonomik hem de kültürel sermayenin düzeyi eşit olmayan bir şekilde dağılmaktadır. Toplumsal yapıları ise bu eşitsizliyi kendi kurumlar araçlarıyla bunu meşrulaştırmaktadır. Bu eşitsizlik yüzünden üst ve orta sınıflar kendine yüksek bir ekonomik ve kültürel sermaye sağlamaktadır.

Öte yandan, eğitim sistemi, aile, yaşam tarzı, inanç sistemi, davranış, kültürel eğilimler, yaşam tarzı, habitus ve düşünce sistemi, farklı sosyal gruplar oluşturmaktan ziyade bunlar toplumsal hiyerarşilerin üretilmesini veya yeniden üretilmesini ve yayılmasını sağlayan araçlardır. Başka bir ifadeyle, toplumsal eşitsizlikler ya da toplumsal tabakalaşmanın yapısı okul sistemi ve bireyin kendi evindeki kültürel bağlantılara bağlı fonksiyonel bir döngü ile devam etmektedir. Eşit olmayan dağıtım, verilen sınıfsal konumları meşrulaştırır ve buna karşılık kültürel sermayenin eşdeğer dağılımı, daha demokratik toplum ve firsat eşitliği arzusunun öncüsü olabilir. Bu anlamda, kültürel sermaye sosyal eşitliğe ulaşmak için önemli bir rol oynamaktadır. $\mathrm{Bu}$ müdahaleci rol, kişisel olarak değil, eğitim sistemi ve bilinç olarak kendilerini kurtarabilir. $\mathrm{Bu}$ hedefe ulaşabilmek için ancak daha adil toplumsal sistemi oluşturmak gerekmektedir.

\section{KAYNAKLAR}

Alpman, Polat (2009), Toplumsal Sinıflar ve Eğitim, Selçuk Üniversitesi, Sosyal Bilimler Enstitüsü, (Yüksek Lisans Tezi), Konya.

Arun, Özgür (2009), Yaşlı Bireyin Türkiye Serüveni: Türkiye'de Yaşlı Bireyler Arasında Kültürel Sermaye Dağılımı, Gaziantep Üniversitesi, Sosyal Bilimler Dergisi, Sayı, 1, Ss, $77-100$.

Avcı, Yasin ve Ataş, Davut (2019), Marxın Sınıf Tasnifi ve Günümüz Kapitalizmine Sermayenin Değişmeyen Nitelikleri, Sosyal Bilimler Enstitüsü Dergisi, Cilt, 27, Sayı2, Ss, 555-583.

Aydın, Kemal (2018), Max Weber, Eşitsizlik ve Toplumsal Tabakalaşma, Journal Economy Culture And Society, Say1, 57, Ss, 245-267.

Başaran, Anıl (2017), Sınıf Kavramının Kökeni Ve Politik Ekonomik Bir Mukayese Politik Ekonomik Kuram, Cilt, 1, Ss,214-237.

Bourdieu, Pierre (2017), Ayrım, Beğeni Yargısının Toplumsal Eleştirisi (Çev; Fırat, Derya Ve Berkkurt Günce), Haretik Basın Yayın, Ankara.

Bourdieu, Pirerre (1984), Sermaye Biçimleri (Çevri, Şahin, Mehmet), Academia

Ekşioğlu, Şefiko (2012), Kültürel Sermaye Ve Ekonomik Kalkınma Arasındaki İlişkinin Girdi Çıktı Analizi Ve Fayda Maliyet Analizi Yöntemleri İle Türkiye İçin Değerlendirilmesi, Kadir Has Üniversitesi, Sosyal Bilimler Enstitüsü, Doktora Tezi, İstanbul.

Erdoğan, Umut (2018), Ekonomik Ve Kültürel Sermaye Bağlamında Sosyal Sınıfların Farklılaşmas1; Ankara Örneği, Hacettepe Üniversitesi, Sosyal Bilimler Enstitüsü, Yüksek Lisans Tezi, Ankara.

Eyce, Berrin (1965), Sosyal Tabakalaşma Tipolojisinde Weberiyan Model, Edebiyat Dergisi. 
Kahraman, Ahmet (2009), Öğretmen Üyelerinin Toplumsal Köken Bağlamında Tüketim Alışkanlıkları İle Yaşam Tarzları Arasındaki İlişki, Hacettepe Üniversitesi, Sosyal Bilimler Enstitüsü, Doktora Tezi, Ankara.

Kapu, Hüsnü (2008), Sosyal Sermaye Ve Organizasyonların Öngürü Yeteneğini Geliştirme Gücü, İktisadi Bilimler Dergisi, Cilt, 22, Sayı1.

Kızılçelik, Sezgin (2013), Marx’ın Sosyolojisi, Batı Sosyolojisini Yeniden Düşünmek, Ana Yayınc1lı, Ankara

Özel, İrfan (2019), Fatih Başakşehir, Muhafazakar Mahallede İktidar Ve Dönüşen Habitus, İletişim Yayınları, İstanbul.

Palabıyık, Adam (2011), Pierre Bourdieu Sosyolojisinde "Habitus" "Sermaye" Ve "Alan" Üzeride, Liberal Düşünçe, Sayı, 61-62, Ss121-141.

Sunar, Lütfi (2018), Sosyal Tabakalaşma; Kavramlar, Kuramlar Ve Temel Meseleler, Nobel Akademik Yayıncılık Eğitim Danışmanlık TİC.LTD, ŞTİ, Ankara

Swartz, David(2011), Kültür Ve İktidar, Pierre Bourdieunün Sosyolojisi, İletişim Yayınları, İstanbul.

Şengönül, Tahran (2008), Toplumunuzda Eğitim Dikey Sosyal Hareketliliği Etkisi, Sosyoloji Dergisi, Say1, 19, Ss, 178-208.

Weber, Max (2006), Sosyoloji Yazıları, (Çeviren: Taha Parla), İletişim Yayınları, İstanbul.

Yanıklar, Cengiz(2010), Kültürel Sermaye, Eğitim Ve Toplumsal Tabakalaşma Pireer Bourdieunün Yeniden Üretim Kurama Eleştirel Bir Bakış, Sosyoloji Dergisi, Sayı, 22, Ss, 121-138.

Yücel, Cemil, Boyac1, Adnan, Demiran, Gökhan Ve Karataş Ebru (2013), Milli Eğitim Örgüt Sisteminde "Kayıt Alanı" (Hinterland) Uygulanmasının Yöresel Işlevselliğinin Değerlendirilmesi ve Ekonomik, Sosyal Ve Kültürel Sermaye Açılarından Doğurduğu Problemlerin Incelenmesi, Pegem Akademi, Cilt,19, Say1, 1, Ss, 135-151.

\section{Yabancı Kaynaklar}

Bourdieu, Pierre (1984), Dictinction, A Social Critique Of The Judgment Of Taste (Translated, Nice, Richard), Harvard University Press, Cambridge.

Dönmezer, Sulhi(1984), Sosyoloji, Ankara.

Lohnson, Lee (2013), Social Stratification, BIBLICAL Theology Bulletin, Volume 43, Number,3, Pages, 155-168.

Shwani, Muhamad (2012), Sociology Of Social Stratification, Awer Publisher, Erbil. 